\title{
A MANAGEMENT OF SPEAKING CLASS STUDY AT SMART ILC PARE KEDIRI
}

\author{
Mustafah
}

\begin{abstract}
The teacher English is challenged should be able to manage the classroom. Descriptive qualitative was the design of this research because a management of speaking class at SMART ILC that was unique. The data collecting method were observation, interview and documentation. The result of this research showed that the tutor strategy in teaching speaking was seating arrangement was strategy to position a good learning pattern for delivering the material as well with the capture of a student seating strategy that is used semicircle, Oral content strategy before starting lesson was done in rotation to remember the material that has been studied. The teaching method of speaking in the outdoors to make students enjoy learning and the atmosphere is cool in the open and surrounded by shady trees. The ability of students in speaking was capability, ability and understanding students that was different every student. A student response about that strategy in teaching speaking that was students and teacher response about strategy is very unique. The teaching strategies used are very effective because students enjoy the teaching methods provided.
\end{abstract}

Key word: a management, speaking class study

\section{INTRODUCTION}

Education is very important in our life. Education has many functions to develop the skills and character form that makes people become dignified to educate in the life of nation and state. . Education aims to develop the potential of self-reliant students and is a democratic citizen and responsible for improving the quality of education and human resources. Therefore, the issue of education is never separated from the dynamics of life. This will always require innovation to improve the quality of learning in order to improve students' skills. They involve teachers who play an important role in solving problems in education.

There are four skills in English learning, they are listening, speaking, reading and writing. Those skills are important to be mastered without ignoring each other. To most people, mastering the art of speaking is the single most important aspect of learning a second or foreign language, and success is measured in terms of the ability to carry out the conversation in the language. So, speaking is very important in language learning because speaking can help us to communicate to the other people.

Speaking becomes one of vital skill in a language. For the reason, to make someone understand is hard to do. Moreover without speaking, it will have many 
misses understanding. Therefore, Speaking need studying. In other side, English has become the international language. English is the most widely spoken language in the world, and if the people know how to speak English, it will be an invaluable tool of communication. Furthermore, English language without speaking becomes silent language. As it is seen, speaking is the priority in teaching and learning English language. Richards (2008:19) stated that "The mastery of speaking skills in English is a priority for many second language or foreign language learners". This most reasoned of the language learner is that they can mastery the language or not is determined on the way hers or his speaking. Therefore, speaking is a top priority in language learning.

In the other hand, in teaching and learning English there various issues were coming up by this case. One of the various issues was classroom management. Practically, it is seldom considered by the teacher in a class whereas management class is supposed to be vital part in teaching and learning. Management class is so important to consider because it becomes the main factor for determining the success of learning and teaching. Harmer (2007:34) stated if we want to manage classroom effectively, we have to be able to handle a range of variables. These include how the classroom space organized, whether students or working on their own or in groups and how we organize classroom time.

Classroom management is one of the important aspects in teaching English. Classroom management that is used by the teacher can influence the teaching English. So, the teacher English are challenged should be able to manage the classroom, including creating and maintaining of the optimal learning conditions. According to Good and Brophy (1994), The finding show that the teachers who approach classroom management as a process of establishing and maintaining effective learning environments tend to be more successfull than teachers who place more emphasis on their role as authority figures or disciplinarians. From the above statements, Classroom management is a term used by teachers to describe the process of ensuring that classroom lessons run smoothly despite disruptive behavior by students. In Miller, (1989:1) Managing the classroom is a critical element in successfull instruction and requires good organizational ability and consistency, and three phases of classroom. Management and discipline; (1) planning before school begins, (2) implementing plans, (3) maintenance (Emmer, 1987). This is the reason researcher takes the title as research is to give the knowledge to the reader aboaut a management of speaking class study at Smart ILC because there are so different from another courses. A tutor has a good strategy for teaching and making a student enjoy for studying. The research was investigated to answer the following questions; (1) How is the tutor strategy in teaching speaking at SMART ILC Pare-Kediri?, (2) How is the ability of students in speaking at SMART ILC Pare-Kediri?, (3) How are students' responses about that strategy in teaching speaking at SMART ILC Pare-Kediri?

\section{Classroom Management}

Garrett (2008:2) stated Classroom management is a multi-faced concept that includes the organization of the physical environment the establishement of rules and routines, the development of effective relationship, and the prevention 
of and response to misbehavior. So, the teacher or educator do a classroom management efforts to raise optimal condition till make students' studying motivation grow and gain learning activity expected.

According to Brown (2000:192), "the next step is a succession of practicalities for the language classroom is to grapple with what we call classroom management, which encompasses an abundance of factors ranging from how you physically arrange the classroom". Classroom management is very close with the success of learning activity situation. Therefore, teacher as classroom management should be skillful to create optimal learning condition by make it stick.

From the explanation above, we can conclude that classroom management is a tool to ease us reach learning purpose. Regina (2014:3) stated that classroom teachers are known as classroom managers because of their roles in managing learning activities, instructional procedures, the prevailing attitudes, feeling and atmosphere in the classroom. So that, teaching and classroom management cannot be separated to solve problem especially for imperfect people, a good classroom management from teachers is needed here.

\section{RESEARCH METHOD}

The design of this study was descriptive qualitative. It was conducted from March $10^{\text {th }}$ to April $10^{\text {th }} 2018$ at SMAR ILC that is located on Cempaka street 09A Kampung Inggris, Pare, Kediri, East Java. Key of informant for this study, they were; the manager was named Mrs Uun, the tutor was named Mrs Nikmah and Mr Munir and the students.

To collect the data the researcher used instrument such as interview, observation, and documentation. Interview was used for collecting data about classroom management in speaking class. Observation was used to collect some information about classroom management and Documentation was used for collecting documents which is related to management class.

The data analysis was based on three concurrent flows of activities, they were: data reduction, data display, and verification. Data reduction was used to classify, direct, and organize the data obtained from interviews, observations, and documentations. Data display was used to present the data in the form of brief description, charts, relationship between categories, and so on. Verification was used to present preliminary conclusion which is still tentative and needed evidence to support strong data collection.

\section{RESEARCH FINDING}

\section{The Tutor Strategy in Teaching Speaking at SMART ILC}

Finding the data related to the tutor's strategy in teaching at SMART ILC, and it describes based on the chosen points of one instrument of research. In the process of teaching and learning, teachers have their own methods in conveying the material to understand the students. Target a tutor in conveying the material is to understand the students with the material that is taught by using the method he has, as for the strategy used tutor in teaching of speaking are: 


\section{Seating Arrangement Strategy}

A tutor has a seating arrangement system to position a good learning pattern for delivering the material as well with the capture of a student seating strategy that is used, the tutor used semicircle formation before the students come to class, the tutor first occupies the class and organizes the class by using the formation, so that when explained better because the class conditions are open nature and sounds with other classes.

The description above is in line with the theory by Rachel Wannarka (2008) mention in their journal with the tittle seating arrangements that promote positive academic and behavioral outcomes: a review of empirical research, the journal. Eight studies that investigated at least two of three common arrangements (i.e., rows, groups or semi-circles) were considered. Results indicate that teachers should let the nature of the task dictate seating arrangements. Based on the results of the above research, the seating arrangement strategy gives a positive effect for students and tutors. This strategy is very good for applied in course institutions as well as in formal institutions because when the teacher explain material directly to the students and the task is done with the individual and not in groups.

2. The teaching method of speaking in the outdoors

Outdoor class is not easy to attract the concentration of students in learning because of various kinds of disorders that make students not focus in learning. Classroom conditions in the outdoors are not so easy to control because many influence from other classes that are outside as well. Classes are set from their respective tutors. Learning effectiveness is in a closed classroom but sometimes bored and saturated, making students less energized. In SMART ILC the outside classroom conditioning is determined from the tutor of each one because of who manages the class is the tutor. With outdoors class to make students enjoy learning and the atmosphere is cool in the open and surrounded by shady trees. Based on the results of the above research that learning outside the room sometimes makes students not focus because of the influence of the environment that is crowded but the students prefer to enjoy learning outside the room because it is more relaxed in learning and can enjoy the natural coolness that exists around it.

\section{Oral content strategy before starting lesson}

Oral material that is in SMART ILC is done in rotation to remember the material that has been studied previously because of the intelligence in SMART ILC continuously. Every student who participates in this class must memorize the material already obtained from tutor. This is strategy before starting lesson to know that students study before joining the class every morningWith such a system makes students eager to learn when coming home from class and have a good preparation before going to class. The oral strategy of material done at SMART ILC adds to the spirit of the students every day with the consequences of being able to scribble off the tutor when not studying the material already given.

The description above is in line with the theory by Yosuo Nakatani (2005) mention in their journal with the tittle The Effects of Awareness-Raising Training 
on Oral Communication Strategy Use. The journal, the findings revealed that participants in the strategy training group significantly improved their oral proficiency test scores, whereas improvements in the control group were not significant. The results of the transcription and retrospective protocol data analyses confirmed that the participants' success was partly due to an increased general awareness of OCSs and to the use of specific OCSs, such as maintenance of fluency and negotiation of meaning to solve interactional difficulties. Based on the results of the above research that the Oral content strategy before starting lesson is very effective than writing, because it helps students understand the verbally. From the researchers concluded that oral material before the start of the lesson helps students recall by verbalizing as described above.

\section{The Ability of Students in Speaking at SMART ILC}

Every student who comes to pare makes learning to speak, automatically has a different ability. They want to start learning to talk from the beginning because of the smart basic lessons. Primary speaking is the basic program that is in SMART ILC to help novice students who want to learn to talk.

1. The student capability in speaking class

Any student who follows the Primary speaking program in SMART ILC in the capture of material or automatic power is very different because it is updated from several factors, ranging from age, pattern, habit and environment before they go to Pare or Kampoeng Inggris. Based on the results of the above research find, every student has different capability in primary speaking.

2. The student ability in speaking class

To know the students' ability to interview the tutor to solve information about the ability of students who follow the primary speaking class.

According to tutor:

For ability of every student in primary speaking in SMART ILC is very different because when the oral material there are still students who get graffiti face. Although there is still a streak they still enthusiastically follow the class and can ask his classmates when coming home from class.

From the explanation above tutor students who follow the primary speaking program to the ability not the same every child. Although they are not the same ability they are enthusiastic to follow the primary speaking lessons in SMART ILC and help each other to learn when coming home from class. Based on the results of the above research find, every student has different ability in primary speaking, because they are different background learning.

\section{Understanding students in speaking class}

To find out the students 'understanding of primary speaking, the researcher interviewed the tutor to obtain information about the students' understanding in the primary speaking class. 
According to tutor:

In the understanding of the students who follow the primary talk of each child in a hurry there is a quick catch, there is a moderate and there are slow even though I want to generalize their understanding still cannot be balanced.

From the explanation above tutor students' understanding of English is very different even though they have high learning motivation because of their different backgrounds. Based on the results of the above research find that every student has different because they have different attitude in class

\section{The Students Response about that Strategy in Teaching Speaking at SMART ILC}

To obtain information about the student's response, the researcher interviewed several students who attended the primary speaking program. There are two assessed focuses. They are student responses about the performance or strategy of tutors in the classroom. An explanation of student responses can be described as follows;

1. Students Response, to know the student's response about the strategy used in the class tutor Primary Speaking by using interviews to students who follow the process of learning in the classroom.

The clever tutor keeps us active in the conversation so we can train our confidence to speak English. With the given teaching strategy makes us active in the class and not feel stiff and easy to ask. (Interview with Teguh P)

From the opinion of the students above explained that the strategy used by tutors in SMART ILC is very unique because the students are very passionate and active during the learning in SMART ILC, as for the response saying that they are interested in the method is fun and does not make students bored for learning to speak although capability, ability and understanding of students are very different but they have a strong motivation to learn in the outdoors class. Based on the results of the above research find, that strategy for learning is good and unique because every course has different strategy for teaching students who want to study English and enjoy for learning.

\section{A Tutor Response}

To find out the tutor's response to the strategy used the researcher interviewed the tutor to obtain information related to the strategy that was taught. According to tutor:

The strategies used above are fun teaching methods so that students are willing to learn with great care and do not get bored while receiving the lesson with a marker mark on their face makes students eager to learn and feel embarrassed when not studying because it is marked by a scratch in their face. Likewise setting the seats are simple circles in order to meet face-to-face with students in the classroom and no one back to back. 
From the tutor response above by using the strategy is to make the teaching and learning process effective with duration of one hour every day in class. Based on the research finding that using the strategy is to make the teaching and learning process effective with duration of one hour every day in class.

\section{CONCLUSION}

1. Seating arrangement is a semi-circle strategy used by tutors to help teaching and learning process that is in SMART ILC so that students more easily understand the explanation of the tutor and face each other and not back to each other.

2. The teaching method of speaking in the outdoors, the classroom in the outdoors is very fun and for those who take the automatic speaking program the class must be active talking. When we class in the open like this in SMART ILC make us not too rigid and can stand whenever important attention to the explanation of the tutor.

3. The oral strategy of the material before the start of the lesson is a method of repetition of the material before the start of the tutor's lesson, the consequences obtained when the student does not study before the class in the morning will get his scribble. Scribble obtained is a marker if the student does not learn or review material before the class. Scribbled in the given have been agreed together before the learning process implemented

4. The student capability in speaking at SMART ILC, Student capture is an individual understanding of each student who brought the automatic lead is very different because in the update of several factors, ranging from age, pattern, habit and environment before they go to Pare or Kampoeng Inggris.

5. The ability and understanding of each student is not the same because influenced from the educational background of students even though they are both learning but the ability and understanding are not the same.

6. Students' responses about that strategy in teaching speaking at SMART ILC; The students 'response were included in two focuses. They were students' response and a tutors' response. Those focuses were good because they got good response from students in line with the theories related.

\section{BIBLIOGRAPHY}

Brown, D. 2000. Principles of Language Learning and Teaching, Fourth Edition. Longman: Pearson Education, Ltd.

Good, T. and Brophy, J. 1994 Looking in Classrooms (6th ed). New York: Harper Collins

Garrett, Tracey. 2008. Student-Centered and Teacher-Centered Classroom Management: a Case Study of Three Elementary Teachers. NEw JERSEY. RIDER UNIVERSITY

Harmer, J. 2007. the Practice of English Language Teaching $4^{\text {th }}$ edition. Cambridge: Pearson Longman 
Richard,A. 2008. Learning to Teach: Belajar untuk Mengajar. Buku Dua. (Penerjemah: Helly Prayitno Soetjipto dan Sri Mulyantini Soetjipto). Yogyakarta: Pustaka Pelajar

Regina N, Osakwe. 2014. Classroom Management: A Tool for Achieving Quality Secondary School Education in Nigeria. Abraka: Delta State University Nigeria

Yosua,N. 2005. The Effects of Awareness -Raising Training on Oral Communication Strategy Use.journal

Wannarka. R. 2008. Seating Arrangement that Ptomote Positive Academic and Behavioural Outcomes: A Review of Empirical Research.journal 